\title{
Evaluation of serum leptin in normal pregnant and non-pregnant women
}

\begin{tabular}{ccc}
\hline Fargeen Ezzaddin* & Feedan Tahseen** & Sardar Nouri Ahmed* \\
\hline & Abstract &
\end{tabular}

Background and objectives: Leptin influences satiety, adiposity, and mechanism is with mechanisms regulating puberty onset, fertility, and pregnancy in various species. This study aimed is to evaluate the serum leptin levels indifferent trimesters of pregnancy and compare with healthy non-pregnant women.

Methods: The study was carried out in Erbil city from January to July 2016. Blood specimens were collected in different medical health centers in Erbil city. The sample consisted of two groups; group one consisted of 60 pregnant healthy female individuals. The pregnant group consisted of three subgroups according to the first, second and third trimesters. Group two (control) consisted of 28 healthy non-pregnant female individuals.

Results: There were statistically significant $(P<0.003)$ elevation in serum leptin in pregnant compared with the non-pregnant group, and among trimesters. Serum leptin in the second trimester was significantly $(P<0.001)$ higher than that of the first and the third trimesters.

Conclusion: Our finding showed that increased serum leptin concentration especially in the second trimester for development of placenta and fetus as a function of leptin.

Keywords: Serum leptin; Pregnancy; Trimester.

\section{Introduction}

Pregnancy, also known as gravidity or gestation, is the state of carrying a developing embryo or fetus within the body, after the union of an ovum and spermatozoa. It usually lasts around 40 weeks from the last menstrual period (LMP) and ends in childbirth. Symptoms of pregnancy may include missed periods, tender breasts, nausea and vomiting, frequent urination, and progressive enlargement of the abdomen. The absolute signs of pregnancy are fetal movement, sounds of the fetal heart, ${ }^{1}$ and demonstration of the fetus by obstetric ultrasonography. ${ }^{2}$ In pregnancy, important changes occur in the body weight of the mother, caused by sodium and water retention and by an increase in body fat tissue, but the mechanisms that regulate maternal and fetal changes in fat mass are poorly understood. Leptin is a hormone produced by adiposities in order to regulate food intake and energy expenditure at the hypothalamic level in human. ${ }^{3}$ Leptin (from Greekleptos, "thin"), the "satiety hormone," is a hormone made by adipose cells that helps to regulate energy balance by inhibiting hunger. Leptin is opposed by the actions of the hormone ghrelin, the "hunger hormone." Both hormones act on receptors in the arcuate nucleus of the hypothalamus to regulate appetite to achieve energy homeostasis. In obesity, a decreased sensitivity to leptin occurs, resulting in an inability to detect satiety despite high energy stores. ${ }^{4}$ Although regulation of fat stores is deemed to be the primary function of leptin, it also plays a role in other physiological processes, as evidenced by its multiple sites of synthesis other than fat cells, and the multiple cell types besides

* Department of Biochemistry, College of Medicine, Hawler Medical University, Erbil, Iraq.

** Department of Physiology, College of Medicine, Hawler Medical University, Erbil, Iraq. 
hypothalamic cells that have leptin receptors. Many of these additional functions are yet to be defined. ${ }^{5}$ Leptin is produced primarily in the adiposities of white adipose tissue. It also is produced by brown adipose tissue, placenta (syncytiotrophoblasts), ovaries, skeletal muscle, stomach (the lower part of the fundic glands), mammaryepithelial cells, bone marrow, and gastric chief cells. Leptin circulates in the blood in free form and bound to proteins. ${ }^{6}$ The placenta produces leptin. Leptin levels rise during pregnancy and fall after childbirth. Leptin is also expressed in fetal membranes and the uterine tissue. Uterine contractions are inhibited by leptin. ${ }^{7}$ Proposed physiological roles for leptin in pregnancy include the regulation of concepts growth and development; fetal/placental angiogenesis; embryonic hematopoiesis; and hormone biosynthesis within maternal-feto placental unit; also leptin plays a role in hyperemesis gravidarum (severe morning sickness of pregnancy), in polycystic ovary syndrome and hypothalamic leptin is implicated in bone growth in mice. ${ }^{8}$ Leptin levels vary exponentially, not linearly, with fat mass. Leptin levels in the blood are higher between midnight and early morning, perhaps suppressing appetite during the night. The diurnal rhythm of blood leptin levels may be modified by meal-timing. ${ }^{9}$ Leptin production is stimulated by the adrenal steroid, ${ }^{10}$ insulin increased plasma leptin level, ${ }^{11}$ neuropeptide $Y$ may also be indirectly involved in leptin production through a feedback mechanism, ${ }^{12}$ while thyroid hormones appear to inhibit leptin secretion, ${ }^{13}$ and finally, leptin level is chronically reduced by physical exercise training. ${ }^{14}$ Rubinaet al. $^{5}$ indicated that serum leptin concentration in females higher than that of males, and another research observed that leptin levels are increased in obesity, and this can eventually produce many of the deleterious negative effects of weight gain such as local inflammatory response..$^{16}$ In order to verify whether leptin participates in the changes in body composition during pregnancy and postpartum, healthy women were studied at specific time periods, and axiological parameters were determined.

\section{Methods}

\section{Design of the Study}

This cross-sectional study was conducted during the period from January to July 2016 in different medical health centers in Erbil city. The sample consisted of two groups. Group one consisted of 60 healthy pregnant women, that consisted of three subgroups according to trimesters, first trimester (22 women), second trimester (20 women), and third trimester (18 women). Group two consisted of 28 healthy nonpregnant women.

\section{Collection of blood samples}

Fasting blood samples were collected from these subjects, by using disposable syringes, $5 \mathrm{ml}$ of early morning venous blood samples were drawn aseptically from each subject, 15 minutes at room temperature. Serum was separated by centrifugation at $4000 \mathrm{rpm}$ for five minutes, and then each subject serum was stored and frozen at $-20 \mathrm{C}$. The clear serum samples were employed for the estimation of leptin, glucose and uric acid.

Estimation of Leptin [human leptin (LEP) ELISA Kit]:

The kit is a sandwich enzyme immunoassay for in vitro quantitative measurement of LEP in human's serum, and tissue homogenates and other biological fluids, performed at Erbil veterinary laboratory center by ELISA, Biotek, ELx, made in the USA.

The principle of procedure:

This kit uses enzyme-linked immune sorbent assay (ELISA) based on the Biotin double antibody sandwich technology to assay the Human Leptin(LEP). Add Leptin (LEP) to the wells. Which are pre-coated with Leptin (LEP) monoclonal antibody and then incubate at $37 \dot{c}$. After that, add anti LEP antibodies labeled with biotin to unite with streptavidin-HRP, which forms an immune complex. Remove unbound 
enzymes after incubation and washing. Add solution $A$ and $B$. Then the solution will turn blue and change into yellow with the effect of acid. The shades of the solution and the concentration and the concentration of Human Leptin (LEP) are positively correlated. ${ }^{17,18}$

\section{Statistical Analysis:}

Data were analyzed with the statistical package for the social science (version 20) for Windows 7.0, and Microsoft Excel worksheet 2010. All descriptive data are expressed as mean \pm standard error of the mean (SEM) and standard deviation (SD) for the selected variable. Differences between pregnant and non pregnant women were assessed using independent sample t-test and analysis of variance (ANOVA-test) to compare among three or more means; Statistical significance was inferred at a two-tailed $P$ value of $<0.05$.

\section{Results}

Table 1 shows the mean $( \pm S D)$ age of the sample, and there was no statistically significant difference between the age of the control group and the pregnant women at the different trimester groups. Table 2 provides the mean BMI in control and three trimesters of pregnancy groups. The results obtained reveal that the mean BMI was 29.02 \pm 1.096 for controls, and $28.04 \pm 0.86, \quad 29.04 \pm 0.87$, and $32.09 \pm 1.35$ in three trimesters respectively. There were non-significant differences between control and pregnant groups. Among three trimesters, the mean BMI non-significantly increase from First trimester to second and third respectively.

Table 1: Mean \pm SE age (years) in pregnant and non-pregnant groups.

\begin{tabular}{lcccc} 
Groups & No. & Mean age (years) \pm S.E & F- test & $P$ value \\
\hline Control & 28 & $30.40 \pm 1.36$ & & \\
Firsttrimester & 22 & $27.64 \pm 1.25$ & 1.1 & 0.250 \\
Secondtrimester & 20 & $28.20 \pm 1.7$ & & \\
Thirdtrimester & 18 & $27.68 \pm 1.39$ & & \\
Total & 88 & $28.65 \pm 1.42$ &
\end{tabular}

Table 2: Mean $\pm S E$ of body mass index $(\mathrm{BMI})\left(\mathrm{Kg} / \mathrm{M}^{2}\right)$ in pregnant and non-pregnant groups.

\begin{tabular}{lllll}
\hline Groups & No. & Mean BMI $\left(\mathbf{K g} / \mathbf{M}^{2}\right) \pm$ S.E & F-test & $\boldsymbol{P}$ value \\
\hline Control & 28 & $29.02 \pm 1.1$ & & \\
Firsttrimester & 22 & $28.04 \pm 0.86$ & 1.19 & 0.450 \\
Secondtrimester & 20 & $29.04 \pm 0.87$ & & \\
Thirdtrimester & 18 & $32.09 \pm 1.35$ & & \\
Total & 88 & $29.41 \pm 1.05$ & & \\
\hline
\end{tabular}


Table 3 shows the mean serum leptin levels in the normal and pregnant groups. The results obtained indicate that the mean level of serum leptin in the pregnant group was significantly higher than that of the normal group $(P<0.003)$. Table 4 provides the mean $S$. leptin levels in control and three different trimester groups. There was a significant difference $(P<0.001)$ among groups of pregnant and non pregnant women. Table 5 provides the mean $\mathrm{S}$. leptin levels in control and three different trimester groups. There was a significant difference $(P<0.001)$ between groups (Control V B, Control V C, and B V C), and there was a significant difference $(P<0.0001)$ between (A VB), while between control ND group $(P=0.03)$.

Table 3: Mean \pm SE of leptin (ng/L) in pregnant and non-pregnant groups.

\begin{tabular}{lccc}
\hline Parameters & $\begin{array}{c}\text { Control Group } \\
\text { (Non Pregnant) } \\
\text { (Mean } \pm \text { SE) }\end{array}$ & $\begin{array}{c}\text { Pregnant Group } \\
\text { (Mean } \pm \text { SE) }\end{array}$ & $\boldsymbol{P}$ value \\
\hline Serum leptin $(\mathrm{ng} / \mathrm{L})$ & $37.96 \pm 2.77$ & $47.7 \pm 1.8$ & 0.003 \\
\hline
\end{tabular}

Note/ Results expressed as Mean \pm S.E. $(P$ value $<0.05)$.

Table 4: Mean $\pm S E$ of Leptin (ng/L) in control and different subgroups of pregnant.

\begin{tabular}{llcccc}
\hline Parameter & Groups & No. & Mean \pm S.E & F- test & $P$ value \\
\hline & Control & 28 & $37.96 \pm 2.7$ & & \\
& Firsttrimester & 22 & $33.25 \pm 3.05$ & & \\
Leptin(ng/L) & Secondtrimester & 20 & $59.20 \pm 3.82$ & 5.29 & $<0.001$ \\
Mean \pm S.E & Thirdtrimester & 18 & $50.66 \pm 3.13$ & & \\
& Total & 88 & $44.21 \pm 3.13$ & & \\
& & & & & \\
\hline
\end{tabular}

Table 5: Mean \pm SE of Leptin (ng/L) in control and compare with each subgroup of pregnant.

\begin{tabular}{|c|c|c|c|c|c|}
\hline Parameter & $\begin{array}{c}\text { Control } \\
28\end{array}$ & $\begin{array}{c}\text { First } \\
\text { trimester } \\
\text { 22(A) }\end{array}$ & $\begin{array}{c}\text { Second } \\
\text { trimester } \\
20 \text { (B) }\end{array}$ & $\begin{array}{l}\text { Third } \\
\text { trimester } \\
18 \text { (C) }\end{array}$ & $P$ value \\
\hline Leptin(ng/L) & & & & & $\begin{array}{l}\text { Control V A } 0.030 \\
\text { Control V B } P<0.001\end{array}$ \\
\hline \multirow[t]{3}{*}{ Mean $\pm S . E$} & $37.96 \pm 2.7$ & $33.25 \pm 3.05$ & $59.20 \pm 3.82$ & $50.66 \pm 3.13$ & Control V C $P<0.001$ \\
\hline & & & & & $A \vee B \quad P<0.0001$ \\
\hline & & & & & $P<0.001$ \\
\hline
\end{tabular}


Table 6 provides the mean levels of Pressure (SBP) and diastolic blood specific gravity and $\mathrm{pH}$ of urine in control and pregnant groups (mean $\pm \mathrm{SE}$ ), there is no any significant $(P>0.05)$ difference of specific gravity and $\mathrm{pH}$ among groups. Table 7 shows the mean levels of pulse rate $(\mathrm{PR})$ (beat/minute), systolic blood pressure (DBP), in control and pregnant groups (mean $\pm \mathrm{SE}$ ), there was no any significant difference $(P>0.05)$ of $\mathrm{PR}$ (beat/minute) among groups, while, there were significant difference $(P<0.05)$ of each SBP and DBP among groups.

Table 6: Mean \pm SE of urine $\mathrm{pH}$ and specific gravity in control and different subgroups of pregnant.

\begin{tabular}{llcccc}
\hline Parameter & Groups & No. & Mean \pm S.E & F- test & $P$ value \\
\hline \multirow{4}{*}{$\mathrm{pH}$} & Control & 28 & $6.21 \pm 0.07$ & & \\
& First trimester & 22 & $6.27 \pm 0.08$ & & \\
& Second trimester & 20 & $6.45 \pm 0.08$ & 0.986 & 0.210 \\
& Third trimester & 18 & $6.12 \pm 0.104$ & & \\
& Total & 88 & $6.26 \pm 0.082$ & & \\
Specific & Control & 28 & $1.020 \pm 0.0019$ & & \\
gravity & First trimester & 22 & $1.025 \pm 0.0013$ & & \\
& Second trimester & 20 & $1.027 \pm 0.0016$ & 0.977 & 0.200 \\
& Third trimester & 18 & $1.025 \pm 0.0016$ & & \\
& Total & 88 & $1.025 \pm 0.0016$ & & \\
\hline
\end{tabular}

Table 7: Mean \pm SE of PR (beat/minute), SBP and $\mathrm{DBP}(\mathrm{mm} \mathrm{Hg})$ in control and different subgroups of pregnant groups.

\begin{tabular}{llcccc}
\hline Parameter & Groups & No. & Mean \pm S.E & F- test & $P$ value \\
\hline & Control & 28 & $80.29 \pm 0.902$ & & \\
Heart rate & First trimester & 22 & $82.36 \pm 1.16$ & & \\
Beat/minute & Second trimester & 20 & $83.10 \pm 1.62$ & 1.52 & 0.350 \\
& Third trimester & 18 & $82.95 \pm 1.915$ & & \\
& Total & 88 & $81.99 \pm 1.34$ & & \\
& Control & 28 & $110.54 \pm 1.69$ & & \\
Systolic blood & First trimester & 22 & $104.77 \pm 1.85$ & & \\
pressure (SBP) & Second trimester & 20 & $104.00 \pm 1.84$ & 2.63 & 0.270 \\
(mmHg) & Third trimester & 18 & $111.32 \pm 2.09$ & & \\
& Total & 88 & $107.77 \pm 1.85$ & & \\
& Control & 28 & $76.79 \pm 1.13$ & & \\
Diastolic blood & First trimester & 22 & $71.59 \pm 1.3$ & & \\
pressure & Second trimester & 20 & $70.25 \pm 2.00$ & 2.73 & 0.200 \\
(DBP) (mmHg) & Third trimester & 18 & $78.16 \pm 2.09$ & & \\
& Total & 88 & $74.28 \pm 1.57$ & & \\
\hline
\end{tabular}




\section{Discussion}

This study was designed to assess serum leptin in pregnant and compare with control group match in ages and BMI, between these two groups in order not to affect the results, but BMI increases gradually in first to third trimester due to normal physiological growth of the baby. In pregnancy, important changes occur in the body weight of the mother, caused by sodium and water retention and by an increase in body fat tissue. ${ }^{2}$ The mean serum leptin in the pregnant group was significantly higher $(P<0.03)$ than that of the control group. This is in agreement with the results obtained by Henson and Castracane, ${ }^{19}$ who revealed that maternal hyperleptinemia is a hallmark of mammalian pregnancy, they concluded that leptin, a polypeptide originating in maternal and fetal adipose tissue and the placenta, is regulated in a tissue-specific manner and plays a variety of physiological roles in pregnancy. The largest source of leptin is adipose tissue, and the next largest source is the placenta. The main effect of leptin is antiobesity. It also plays a role in early human development, pregnancy, and reproductive function. Hypoxia and hyperglycemia are the triggering factors for increased leptin production by the placenta by the transcriptional changes in the leptin gene. It is unclear whether leptin levels influence the fetal growth. ${ }^{20}$ Among three trimesters, the mean serum leptin were significantly difference $(P<0.001)$ among groups, the same results obtained by Castellano et al., ${ }^{21}$ they obtained that body weight regulation by leptin during the second half of pregnancy does not follow the physiologic role as an adipose with negative feedback to CNS that is classically attributed to leptin. They revealed a positive association between higher second trimester leptin levels and greater subsequent gestational weight gain in normal-weight women, and this association was stronger in overweight women. These findings suggest a potential feed forward mechanism where higher leptin levels could signal the need to increase food intake and lead to greater weight gain. Feed forward loops are rare in human physiology, but are well known in the reproductive endocrine system such as the menstrual cycle. Mechanistic studies will be necessary to test this hypothesis and elucidate these mechanisms at the CNS and peripheral levels. Tessier DR et al. $2013^{22}$ concluded that in later stages of a healthy pregnancy, central leptin resistance occurs to allow increased nutrient availability for the fetus, the same results obtained in this study when serum leptin in the third trimester significantly lower than that of the second trimester. Disruption of signaling capacity of leptin associated with obesity is emerging as a potential risk factor leading to pregnancy complications as a result of aberrant fuel portioning in the uterus. Deregulation of leptin metabolism and/or function in the placenta may be implicated in the pathogenesis of various disorders during pregnancy, such as recurrent miscarriage, gestational diabetes, intrauterine growth retardation, and preeclampsia. ${ }^{23}$ Therefore, leptin appears to play a major role in organogenesis which may adversely affect the risk of developing a number of diseases in adulthood. ${ }^{24}$ In this study, the determined specific gravity and $\mathrm{pH}$ in the urine of both groups (control and pregnant groups), in comparison among groups there were no statistically significant differences $(P>0.05)$. This is in agreement with the results obtained by Armstrong et al., ${ }^{25}$ and this is it may be caused by physiological albuminuria which causes increase acidity and specific gravity of pregnant urine, and it may be related to high level of serum leptin in second trimester, compared with first and third trimesters. From the study determined of heart rate, in control and different subgroups of pregnant, in comparison among groups there were no statistically significant differences $(P>0.05)$, but among trimesters groups, but about both 
SBP and DBP, there were significant difference $(P<0.05)$ among groups, this is in agreement with the results obtained by Krucik 2016, ${ }^{26}$ and this is it may be due to physiological increase body mass index $\left(\mathrm{BMl} \mathrm{kg} / \mathrm{M}^{2}\right.$ ) caused by development and growth the fetus.

\section{Conclusion}

High levels of serum leptin in pregnancy are caused by the development of the placenta and the influence the fetal growth. There was a significant difference in the serum leptin level of controls, and the three trimesters, among groups. In all trimesters of the pregnant group, there was a normal heart rate, systolic and diastolic pressures. Also in urine examination, there was normal specific gravity and $\mathrm{pH}$.

\section{Competing interests}

The authors declare that they have no competing interests.

\section{References}

1. Michelle A. Dornald's illustrated medical dictionary. $29^{\text {th }}$ ed. London: W.B. Sounders company; 2007. P. 145-6.

2. Whitworth M, Bricker L, Neilson JP, DowswellT. Ultrasound for fetal assessment in early pregnancy. Cochrane Database of Systematic Reviews 2014; (4):546-8.

3. Lage M, Garcia-Mayor RV, Tomé MA, Cordido F, Valle-Inclan F, Considine R U, et al. Serum leptin levels in women throughout pregnancy and the postpartum period and in women suffering spontaneous abortion. Clinical Endocrinol 1999; 50(2):211-6.

4. Pan H, Guo J, Su Z. Advances in understanding the interrelations between leptin resistance and obesity. Physiology \& Behavior 2014; 130:15769.

5. Pelleymounter MA, Cullen MJ, Baker MB, Hecht $\mathrm{R}$, Winters D, Boone T, Collins F. Effects of the obese gene product on body weight regulation in ob/ob mice. Science 1995; 269(5223):540-3.

6. Margetic S, Gazzola C, Pegg GG, Hill RA. Leptin: a review of its peripheral actions and interactions. Int J Obes Relat Metab Disord 2002; 26(11):1407-33.

7. Aka N, Atalay S, Sayharman S, Kiliç D, Köse G, Küçüközkan T. Leptinand leptin receptor levels inpregnant women with hyperemesis gravidarum. The Aust N Z J Obstet Gynaecol 2006; 46(4):2.

8. Cervero A, Domínguez F, Horcajadas JA,
Quiñonero A, Pellicer A, Simón C. The role of the leptin in reproduction. Current Opinion in Obstetrics and Gynecology 2006; 18(3):297303.

9. Schoeller DA, Cella LK, Sinha MK, Caro JF. Entrainment of the diurnal rhythm of plasma leptin to meal timing. J Clin Invest 2006; 100(7):1882-4.

10. Murakami T, Lida M,Shima K. Dexamethazone regulates obese expression in isolated rat adipocytes. Biochem Biophys Res 2005; 214:1260-7.

11. Covey SD, Wideman RD, McDonald C, Unniappan S, Huynh F, Asadi A, et al. The pancreatic beta cell is a key site for mediating the effects of leptin on glucose homeostasis. Cell Metab 2006; 4:291-302.

12. Bjorback KB, Khan $H$. Leptin signaling in the CNS and peripheral. Recent progress in hormone Research 2004; 59:305-31.

13. Hardie LM, Guilhot N, Trayhurn P. Regulation of leptin production in culture matured white adipocytes. Horm Metab 1996; 25(12):685-9.

14. De Salles BF, Simao R, Fleck SJ, Dias I, Kraemer-Aguiar LG, Bouskela E. Effects of resistance training on cytokines. Int J Sports Med 2010; 31(7):441-50.

15. Rubina F B, Hassan M, Nazar HS, Gillani S, Naeema A, Qayyum I. Effect of body mass index on serum leptin levels. J Ayub Med Coll Abbottabad 2011; 23:(3)40-3.

16. Fantuzzi G. Adipose tissue, adipokines, and inflammation. J Allergy Clin Immunol 2005; 115:911-20.

17. Pakajara N. Biochemistry. $3^{\text {rd }}$ ed. New Delhi: Jaypee Brothers Medical Pub 2010. P.1123-5.

18. Goodman H M. Basic medical endocrinology. $4^{\text {th }}$ ed.USA: Elsevier science; 2008.P. 120-3.

19. Henson MC, Castracane VD. Leptin in pregnancy. Biol Reprod 2000; 63(5):1219-28.

20. Shilpa GB. Management of diabetes in obstetrics and gynecology. $1^{\text {st }}$ ed. New Delhi: Jaypee Brothers Medical Pub 2009. P. 9-11.

21. Castellano Filho DS, do Amaral Correa JO, Dos Santos Romas P, de Oliveria Montessi M, Aarestrup BJ, Aarestrup FM. Body weight gain and serum leptin levels of non-overweight and overweight/obese pregnant women. Med Sci Monit 2013; 19:1043-9.

22. Tessier DR, Ferraro ZM, Gruslin A. Role of leptin: consequences of maternal obesity. Placenta 2013; 34(3):205-11.

23. Sagawa N, Yura S, Itoh H, Kakui K, Takemura $\mathrm{M}$, Nuamah $\mathrm{M}$, et al. Possible role of placental leptin in pregnancy: a review. Endocrine 2002; 19(1):65-71.

24. Briffa JF, McAinch AJ, Romano T, Wodek ME, Hryciw DH. Leptin in pregnancy and development: a contributor to adulthood disease? Am J Physiol Endocrinol Metabol 2014;10(1152). 25. Armstrong LE, Soto JA, Hacker FT, Casa DJ, 
Evaluation of serum leptin in normal pregnant .......

Zanco J. Med. Sci., Vol. 22, No. (3), December, 2018 https: //doi.org/10.15218/zjms.2018.041

Kavouras SA, Maresh CM. Urinary indices during dehydration, exercise, and rehydration. Int $\mathrm{J}$ Sport Nutr 1998; 8:345-55.

26. Krucik GT. High blood pressure during pregnancy. Health line 2016; 20:1-8. 